\title{
Importance of Individual Ghost Cells in Fine-Needle Aspiration Cytology Diagnosis of Pilomatricoma
}

Kanghee Han · Hwa-Jeong Ha Joon Seog Kong · Jae Kyung Myung ${ }^{1}$ Sunhoo Park · Jung-Soon Kim Myung-Soon Shin · Hye Sil Seol Jae Soo Koh · Seung-Sook Lee ${ }^{1}$

Department of Pathology, Korea Cancer Center Hospital, Korea Institute of Radiological and Medical Sciences (KIRAMS), Seoul; ${ }^{1}$ Laboratory of Radiation Pathology, Korea Institute of Radiological and Medical Sciences (KIRAMS), Seoul, Korea

Received: August 31, 2017

Revised: September 30, 2017

Accepted: October 16, 2017

\section{Corresponding Author}

Seung-Sook Lee, MD, PhD

Department of Pathology, Korea Cancer Center Hospital, Korea Institute of Radiological and Medica Sciences (KIRAMS), 75 Nowon-ro, Nowon-gu,

Seoul 01812, Korea

Tel: +82-2-970-1268

Fax: +82-2-970-2430

E-mail: sslee@kirams.re.kr
Background: Although histological diagnosis of pilomatricoma is not difficult because of its unique histological features, cytological diagnosis through fine-needle aspiration cytology (FNAC) is often problematic due to misdiagnoses as malignancy. Methods: We reviewed the cytological features of 14 cases of histologically-proven pilomatricoma from Korea Cancer Center Hospital, with a discussion on the diagnostic pitfalls of FNAC. Results: Among 14 cases of pilomatricoma, 10 (71.4\%) were correctly diagnosed through FNAC, and two (14.3\%) were misdiagnosed as carcinoma. Cytologically, all cases had easily recognizable clusters of basaloid cells and foreign body-type multinucleated cells. Although ghost cells were also found in all cases, some were inconspicuous and hardly recognizable due to their small numbers. Conclusions: An accurate diagnosis of pilomatricoma in FNAC is feasible with consideration of clinical information and close examination of ghost cells.

Key Words: Pilomatricoma; Fine-needle aspiration cytology; Ghost cells
Pilomatricoma is a benign subcutaneous or dermal adnexal tumor that is usually a solitary nodule located at the head, neck, or upper limb. ${ }^{1}$ Although it occurs in all age groups, 30\%$50 \%$ of cases arise in individuals under the age of $30 .^{2}$ Histologically, pilomatricoma has conspicuous features that are well recognized, including aggregations of basaloid cells and inner eosinophilic material containing ghost cells. ${ }^{2}$ Ghost cells are characterized by keratinized eosinophilic cells with distinctive cell borders and central unstained areas that correspond to the lost nuclei. ${ }^{3}$ Because of these unique histological features, pilomatricoma is easy to diagnose on histologic sections. However, cytomorphological features of pilomatricoma found in aspirates are less distinctive and may mimic other benign lesions or malignant tumors. ${ }^{4-7}$ Moreover, pilomatricoma is not infrequently mistaken for malignancies by positron emission tomography/ computed tomography (PET/CT) as well as fine-needle aspira- tion cytology (FNAC). ${ }^{8-11}$ Increased fluorodeoxyglucose (FDG) uptake in PET/CT generally suggests malignancy, but benign conditions such as infection/inflammation, lymphoid hyperplasia, granulomatous disease, and foreign body reactions may present as false-positive results. ${ }^{12,13}$ Therefore, high FDG uptake of pilomatricoma in PET/CT might be attributed to a foreign body reaction in an area of keratinization. ${ }^{8}$ Previous studies have shown diverse rates of preoperative diagnosis of pilomatricoma on FNAC, ranging from $1.1 \%$ to $81.9 \% .^{14,15}$ Misdiagnosis, especially as malignancy, can lead to unnecessary treatment for patients with pilomatricoma. Here, we sought to delineate which cytomorphologic findings were useful in reliably differentiating pilomatricoma from other tumors, particularly from cancer. 


\section{MATERIALS AND METHODS}

We identified 56 cases of pilomatricoma with a tissue diagnosis between January 1991 and December 2011 using the pathology database of the Department of Pathology at Korea Cancer Center Hospital (KCCH, Seoul, Korea). FNAC was performed in 14 out of those 56 cases prior to surgical resection.

Aspirations were performed with a 22-25-gauge needle attached to a 10 cc disposable syringe. The collected samples were smeared on slides, fixed with 95\% ethyl alcohol, and stained with Papanicolaou stain.

A morphological analysis was done of the FNAC slides. The slides were reviewed by two pathologists and one cytotechnologist.

Cytomorphology focused on ghost cells, basaloid cells, nucleated squamous cells, calcium deposits, multinucleated giant cells, and the background, with scoring using a semiquantitative method (-, absent; +, small amount: occasionally observed; ++, moderate amount: easy to detect; +++ , abundant: frequently detected in aggregates and/or isolated cells).

This study was approved by the Institutional Review Board of Korea Cancer Center Hospital with a waiver of informed consent (IRB No. K-1710-002008).

\section{RESULTS}

\section{Clinicopathological findings}

The present study included 14 cases of eight female and six male patients with ages ranging from 4 to 38 years (mean age, 18.4 years). All cases presented as a single mass in the head and neck region. Lesion size varied from 0.3 to $3 \mathrm{~cm}$ (mean, $1.3 \mathrm{~cm}$ ). Clinical impressions were diverse; ten cases were benign and the other four cases were considered as malignancies, including metastasis from the salivary gland, thyroid, or metastasis of unknown origin. In our series, a correct diagnosis as pilomatricoma by FNAC was made in 10 cases (71.4\%) and misdiagnosis was made in four cases $(28.6 \%)$. The erroneous diagnoses included metastatic carcinoma (2 cases), atypical cells ( 1 case), and benign lymphadenopathy (1 case). Relevant clinical data and initial FNAC diagnoses are summarized in Table 1.

Histologically, all cases showed typical morphology of pilomatricoma, including two distinct populations of ghost cells and peripheral sheets of basaloid epithelial cells in varying proportions. Basaloid cells had round to oval hyperchromatic nuclei and scanty eosinophilic cytoplasm. Ghost cells had a distinct cell border and eosinophilic cytoplasm without nuclei, displaying an empty central portion.

\section{Cytological features}

The aspirates of the fourteen cases included in this study showed varying proportions of cellular components, including ghost cells, basaloid cells, nucleated squamous cells, calcium deposits, and multinucleated giant cells (Fig. 1). Importantly, basaloid cells, ghost cells and multinucleated giant cells were found in all 14 cases, and their amounts varied in each case.

Basaloid cells were usually observed as cohesive clusters and easily detected in most cases. Although they tended to form monolayer sheets of small uniform cells, hyperchromatic nuclei and conspicuous nucleoli were enough to raise the suspicion of

Table 1. Clinicopathological findings in 14 cases of pilomatricoma

\begin{tabular}{|c|c|c|c|c|c|c|}
\hline Case No. & Sex & Age (yr) & Location & Tumor size (cm) & Clinical diagnosis & Initial FNAC diagnosis \\
\hline 1 & $\mathrm{~F}$ & 36 & Neck & 0.6 & Benign mass & Pilomatricoma \\
\hline 2 & $\mathrm{~F}$ & 21 & Preauricular & 0.3 & Metastatic carcinoma & Atypical cells \\
\hline 3 & $\mathrm{~F}$ & 4 & Preauricular & 3 & Tuberculosis & Metastatic carcinoma of salivary origin \\
\hline 4 & $\mathrm{~F}$ & 10 & Neck & 0.5 & Tuberculosis & Pilomatricoma \\
\hline 5 & $\mathrm{~F}$ & 6 & Mandible & 1 & $\begin{array}{l}\text { Inclusion cyst, r/o tuberculosis, } \\
\text { r/o carcinoma }\end{array}$ & $\begin{array}{l}\text { Atypical epithelial cells, suspicious } \\
\text { for metastatic carcinoma }\end{array}$ \\
\hline 6 & $\mathrm{~F}$ & 38 & Posterior neck & 0.6 & $\begin{array}{l}\text { Metastatic carcinoma (history: papillary } \\
\text { carcinoms of thyroid) }\end{array}$ & Pilomatricoma \\
\hline 7 & M & 37 & Neck & 1 & MUO & Lymphadenitis \\
\hline 8 & M & 19 & Neck & 1.5 & Benign mass & Pilomatricoma \\
\hline 9 & $F$ & 16 & Neck & 1 & $\begin{array}{l}\text { Reactive hyperplasia } \\
\text { r/o epidermal cyst }\end{array}$ & Pilomatricoma \\
\hline 10 & $\mathrm{~F}$ & 19 & Parotid gland & 2.3 & Pilomatricoma & Pilomatricoma \\
\hline 11 & M & 11 & Preauricular & 1 & Epidermal cyst & Pilomatricoma \\
\hline 12 & M & 11 & Postauricular & 2.2 & Epidermal cyst & Pilomatricoma \\
\hline 13 & M & 14 & Neck & 1.7 & Lymphadenitis & Pilomatricoma \\
\hline 14 & M & 16 & Neck & 1.7 & Neck mass & Pilomatricoma \\
\hline
\end{tabular}

FNAC, fine-needle aspiration cytology; F, female; M, male; MUO, metastasis of unknown origin; r/o, rule out. 
carcinoma (Fig. 1B). Nuclear pleomorphism was not found but mitosis was detected in one case. The number of basaloid cell nests was relatively small in eight cases (Table 2).

On the FNAC smears, all 14 cases displayed ghost cells. However, ten of the cases presented with only a small amount of ghost cells detected with careful observation, one case had an easily detectable moderate amount, and only three cases had abundant and frequently observed ghost cells (Table 2, Fig. 2). It was easy to notice in the four cases with sheet-forming ghost cells that they were characteristic ghost cells derived from pilomatricoma, in contrast with the five cases where ghost cells only constituted a very small number of individual cells. The relative appearance rates of basaloid cells and ghost cells also varied. As shown in Table 2, five cases showed a relative abun-
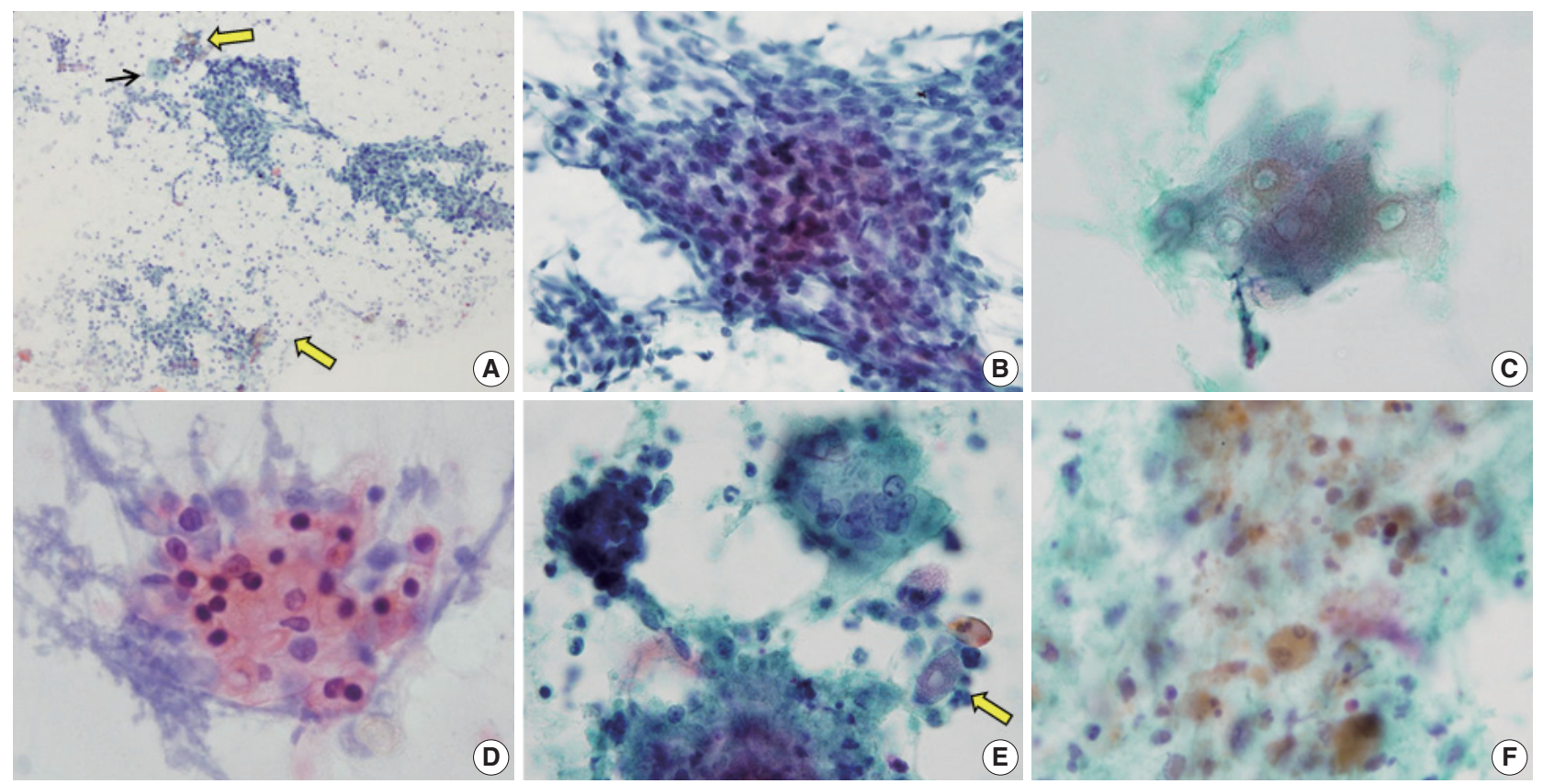

Fig. 1. Cytological features of pilomatricoma. (A) Low power view exhibiting large clusters of basaloid cells, ghost cells (thick arrows), and a multinucleated giant cell (thin arrow) in an inflammatory background. (B) Large clusters of basaloid cells mimicking carcinoma. (C) Ghost cells. (D) Nucleated squamous cells. (E) Foreign body-type multinucleated giant cell (right upper), small cluster of basaloid cells (left upper), calcific debris (lower), isolated ghost cell (arrow), and inflammatory cells. (F) Cellular debris (Papanicolaou stain).

Table 2. Cytological features in 14 cases of pilomatricoma

\begin{tabular}{|c|c|c|c|c|c|c|c|}
\hline \multirow[b]{2}{*}{ Case No. } & \multirow[b]{2}{*}{ Initial FNAC diagnosis } & \multicolumn{6}{|c|}{ Cytological feature } \\
\hline & & $\begin{array}{l}\text { Ghost } \\
\text { cells }\end{array}$ & $\begin{array}{l}\text { Basaloid } \\
\text { cells }\end{array}$ & $\begin{array}{l}\text { Nucleated squamous } \\
\text { cells }\end{array}$ & $\begin{array}{l}\text { Calcium } \\
\text { deposits }\end{array}$ & $\begin{array}{l}\text { Giant } \\
\text { cells }\end{array}$ & Background \\
\hline 1 & Pilomatricoma & + & ++ & ++ & ++ & + & Debris, inflammatory \\
\hline 2 & Atypical cells & + & + & - & - & + & Bloody \\
\hline 3 & Metastatic carcinoma of salivary origin & + & ++ & + & - & ++ & Bloody \\
\hline 4 & Pilomatricoma & +++ & + & + & - & + & Debris \\
\hline 5 & $\begin{array}{l}\text { Atypical epithelial cells, suspicious } \\
\text { for metastatic carcinoma }\end{array}$ & + & +++ & + & + & + & Debris \\
\hline 6 & Pilomatricoma & + & +++ & - & + & + & Debris \\
\hline 7 & Lymphadenitis & + & + & - & + & + & Inflammatory \\
\hline 8 & Pilomatricoma & + & + & + & + & + & Clear \\
\hline 9 & Pilomatricoma & +++ & + & - & - & + & Clear \\
\hline 10 & Pilomatricoma & +++ & +++ & + & - & + & Debris \\
\hline 12 & Pilomatricoma & + & ++ & ++ & + & + & Debris, mitosis \\
\hline 13 & Pilomatricoma & ++ & + & + & + & ++ & Cystic \\
\hline 14 & Pilomatricoma & + & + & - & + & + & Inflammatory \\
\hline
\end{tabular}

FNAC, fine-needle aspiration cytology; -, absent; +, mild; ++, moderate; +++, abundant. 

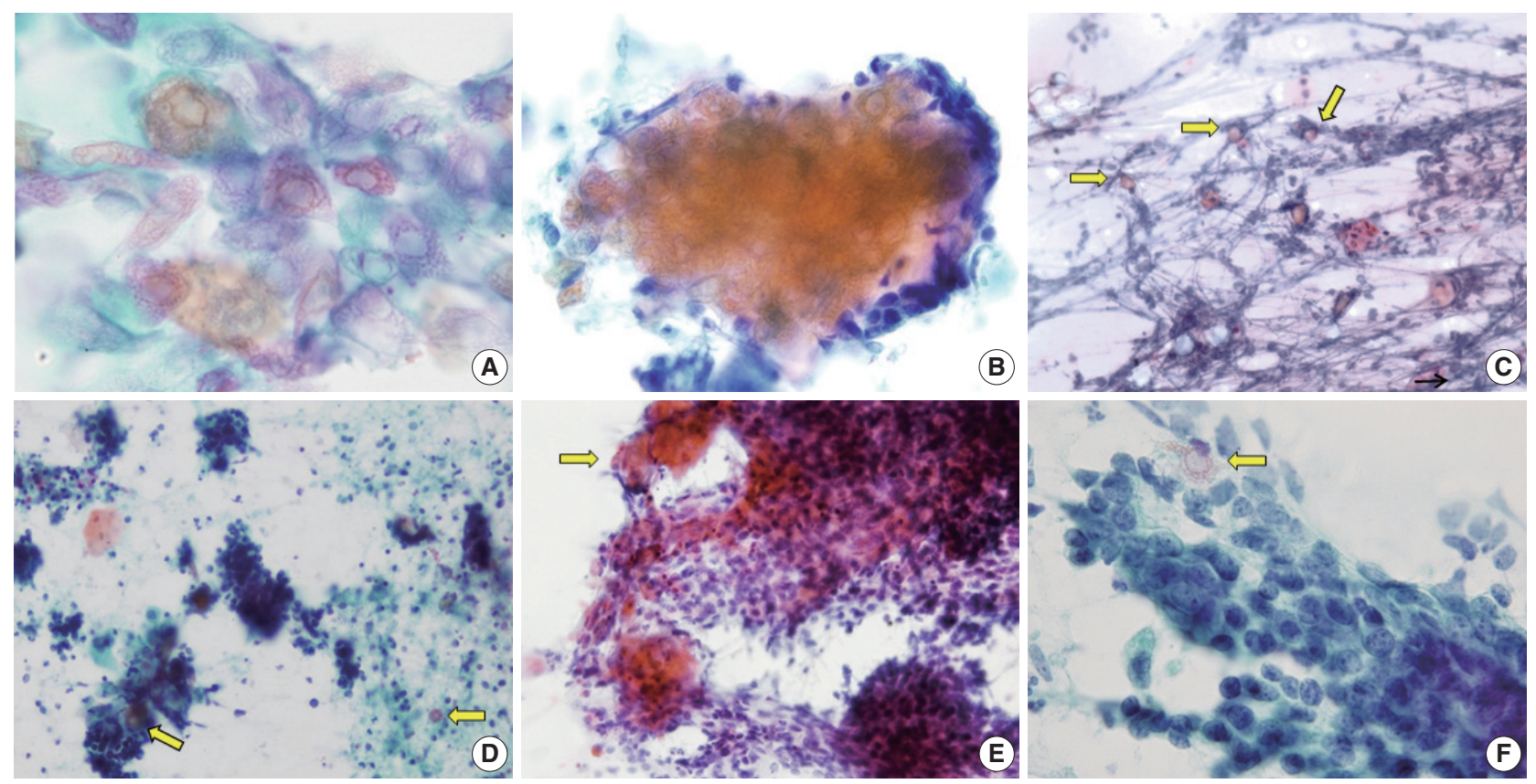

Fig. 2. Variable features of ghost cells in aspirates of pilomatricoma. (A) Ghost cell sheet showing abundant cytoplasm with distinct cell borders and central unstained area. (B) Clusters of ghost cells with peripheral basaloid cells. (C) Isolated ghost cells (arrows) and a small cluster of nucleated squamous cells in an inflammatory background. (D) Predominance of basaloid cell clusters and a few ghost cells (arrows). (E) Ghost cell nests (arrow) at the periphery of a large cluster of basaloid cells. (F) A single ghost cell (arrow) can be overlooked due to a basaloid cell cluster.

dance of basaloid cells compared to ghost cells (cases 1, 3, 5, 6, and 12). Among the five cases, two were misdiagnosed as malignancy or suspicious malignancy, but the other three were correctly diagnosed as pilomatricoma. On the other hand, the FNAC diagnosis was correct in the three cases where ghost cells were abundant or moderate but basaloid cells were present in small amounts (cases 4, 9, and 13). In addition, the case with both abundant basaloid cells and ghost cells (case 10) was correctly diagnosed on FNAC.

Foreign body-type giant cells were also present in all the cases in varied amounts, and were most frequent in two cases (cases 3 and 13). Nucleated squamous cells presented in eight cases. Calcium deposits were found in eight cases. The background showed keratin, cellular debris, blood, and inflammatory cells. These findings are summarized in Table 2 and shown in Fig. 1. As for the four misdiagnosed cases, ghost cells were present, even though they were not easily detected due to their small amounts. In the two cases that were initially either mistaken for metastatic carcinoma (case 3) or suspicious for metastatic carcinoma (case 5), basaloid cells overwhelmed ghost cells (Fig. 2D, F). In both cases, multinucleated giant cells and inflammatory cells were accompanied in the background by blood (case 3) or necrotic debris (case 5). In case 2 , which was initially over-diagnosed as atypical cells, both basaloid cells and ghost cells appeared in small numbers, although the basaloid cells looked atypical due to the high nuclear/cytoplasmic ratio. Finally, case 7, which was erroneously diagnosed as lymphadenitis, showed mainly inflammatory cells, some calcium deposits, and giant cells with a few scattered basaloid cells and ghost cells.

\section{DISCUSSION}

Pilomatricoma is a benign skin adnexal tumor that commonly occurs in the head and neck of young adults or children. ${ }^{11}$ It is not infrequent for pilomatricoma to be misdiagnosed as a malignant tumor in FNAC, which is problematic because the patient is then over-treated. From our observations, we suggest that it is important to recognize that ghost cells can appear in a wide variety of forms (Fig. 2). The presence of ghost cells is of value in the diagnosis of pilomatricoma, but the small amount of individual ghost cells may be overlooked in aspirates. Accordingly, detection of ghost cells, even a few by careful observation appears to be the most important way to reach a correct diagnosis of pilomatricoma in conjunction with clinical information.

In previous studies of 179 cases of pilomatricoma by Lan $e t$ al. ${ }^{14}$ only two cases were correctly diagnosed as pilomatricoma 

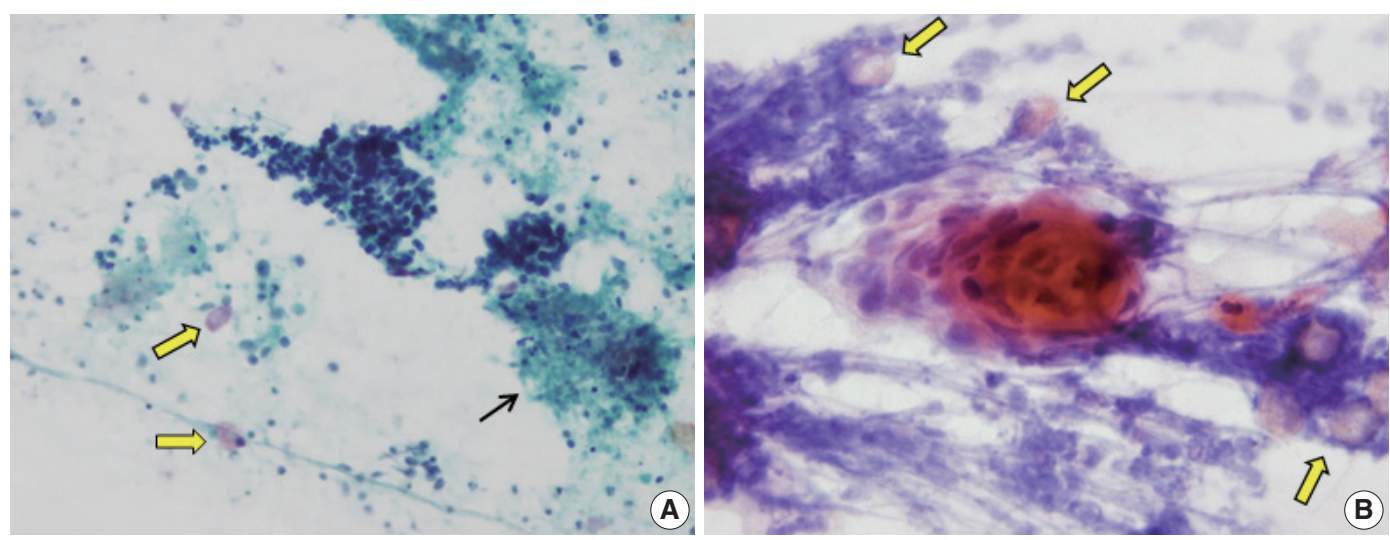

Fig. 3. Fine-needle aspiration cytology smear from pilomatricoma mimicking carcinoma. (A) Tight clusters of basaloid cells and necrotic debris (thin arrow) simulate carcinoma. However, a few scattered ghost cells are noted (thick arrows). (B) A nest of nucleated keratinizing squamous cells (center) may raise the suspicion of carcinoma. Nevertheless, if ghost cells are noted (arrows), a correct diagnosis of pilomatricoma can be made.

in preoperative examination. The other cases were mostly misdiagnosed as benign skin lesions such as epidermoid cysts. ${ }^{16}$ In our series, a correct diagnosis of pilomatricoma by preoperative FNAC was made in 10 cases (71.4\%). All of those cases had ghost cells, basaloid cells, and giant cells. The presence of nucleated squamous cells, calcium deposits, and background varied. Pilomatricoma is often confused with malignant tumors such as small round cell tumor, ${ }^{17,18}$ rhabdomyosarcoma, ${ }^{6}$ Merkel cell carcinoma, ${ }^{7}$ or metastatic small cell carcinoma of the lung ${ }^{19}$ due to the aggregation of basaloid cells with small nuclei and scanty cytoplasm. In addition, because of the unusual location, incorrect diagnosis has been made as metastatic adenocarcinoma in the abdominal wall ${ }^{5}$ and breast cancer. ${ }^{20}$

In the current study, two cases mistaken for carcinomas showed numerous small and large clusters of hyperchromatic epithelial cells. Background cellular debris mimicking tumor necrosis (Fig. 3A) and small clusters of keratinizing cells may have led to a false positive diagnosis (Fig. 3B). Moreover, the ghost cells were not easily detected on the smears, especially in the hypercellular cases, because they were present individually or obscured by inflammatory cells, blood cells, or necrotic debris.

Given the causes of misdiagnosis as malignancy in this study, we have two observations. One is that clinical information, especially patient age, was neglected, and the other is that a few ghost cells were overlooked due to the overwhelming number of basaloid cells. It was careless to suggest metastatic carcinoma in children. Even if malignancy is suspected by cytologic findings, patient age is an important consideration in careful diagnosis.

The current study is limited by the small number of cases. During the same period, 56 cases were diagnosed as pilomatricoma by surgical excision and only 14 cases underwent preop- erative FNAC (25\%) in this study. This is similar to other studies in the literature. Compared to the number of surgically resected tissue specimens, the number with FNAC is relatively small, ranging from $26 \%$ to $53.6 \%$. $^{7,14,21,22}$ Few reports are available on the cytological features of pilomatricoma, and the largest series in the literature includes 22 cases. $^{7}$ This deficit might be due to surgical excision without a preoperative cytologic examination depending on the clinical impression of a benign-looking mass.

In conclusion, consideration of clinical manifestation in patient age, location, consistency, and skin mobility is very important to avoid over-diagnosis in interpreting preoperative FNAC smears of pilomatricoma. It is also important to try to identify the coexistence of basaloid cells and ghost cells, and to avoid focusing too much on a predominance of basaloid cells.

\section{Conflicts of Interest}

No potential conflict of interest relevant to this article was reported.

\section{Acknowledgments}

This study was supported by a grant from the Korea Institute of Radiological and Medical Science (KIRAMS), funded by the Ministry of Science, ICT and Future planning, republic of Korea $(1711045543 ; 1711045540 / 50476-2017)$.

\section{REFERENCES}

1. Fletcher CD. Diagnostic histopathology of tumors. 4th ed. Philadelphia: Elsevier Saunders, 2013; 1707.

2. LeBoit PE, Burg G, Weeden D, Sarasain A. World Health Organiza- 
tion classification of tumours: pathology and genetics of skin tumours. Lyon: IARC Press, 2006; 153-5.

3. Domanski HA, Domanski AM. Cytology of pilomatrixoma (calcifying epithelioma of Malherbe) in fine needle aspirates. Acta Cytol 1997; 41: 771-7.

4. Agrawal L, Kaur P, Singh J, Singh N. Pilomatrixoma misdiagnosed as round cell tumor on fine-needle aspiration cytology. Indian J Cancer 2010; 47: 483-5.

5. Sharma D, Agarwal S, Jain LS, Kamal V. Pilomatrixoma masquerading as metastatic adenocarcinoma: a diagnostic pitfall on cytology. J Clin Diagn Res 2014; 8: FD13-4.

6. Singh S, Gupta R, Mandal AK. Pilomatrixoma: a potential diagnostic pitfall in aspiration cytology. Cytopathology 2007; 18: 260-2.

7. Wang J, Cobb CJ, Martin SE, Venegas R, Wu N, Greaves TS. Pilomatrixoma: clinicopathologic study of 51 cases with emphasis on cytologic features. Diagn Cytopathol 2002; 27: 167-72.

8. Bhatt MK, Sommerville R, Ravi Kumar AS. FDG PET/CT appearance of benign pilomatricoma. Clin Nucl Med 2012; 37: 684-6.

9. Tay JK, Nga ME, Loh KS. Pilomatricoma of the cheek: a benign tumor mimicking metastatic squamous cell carcinoma on FDG PET/ CT. Am J Otolaryngol 2014; 35: 452-5.

10. Szturz P, Rehák Z, Koukalová R, Adam Z, Mayer J. FDG-PET positive pilomatrixoma: reconsidering multicentricity in Langerhans cell histiocytosis. Nucl Med Rev Cent East Eur 2014; 17: 94-6.

11. Jung YS, Kang JG, Park WS, Ryu J. Pilomatricoma: diagnostic pitfalls in PET/CT and fine-needle aspiration biopsy. Otolaryngol Head Neck Surg 2007; 137: 845-6.

12. Pirouzmanesh A, Reinisch JF, Gonzalez-Gomez I, Smith EM, Meara JG. Pilomatrixoma: a review of 346 cases. Plast Reconstr Surg 2003; 112: 1784-9.
13. Rosenbaum SJ, Lind T, Antoch G, Bockisch A. False-positive FDG PET uptake: the role of PET/CT. Eur Radiol 2006; 16: 1054-65.

14. Lan MY, Lan MC, Ho CY, Li WY, Lin CZ. Pilomatricoma of the head and neck: a retrospective review of 179 cases. Arch Otolaryngol Head Neck Surg 2003; 129: 1327-30.

15. Cigliano B, Baltogiannis N, De Marco M, et al. Pilomatricoma in childhood: a retrospective study from three European paediatric centres. Eur J Pediatr 2005; 164: 673-7.

16. Al-Khateeb TH, Hamasha AA. Pilomatricoma of the maxillofacial area in the northern regional Jordanian population: report of 31 cases. J Oral Maxillofac Surg 2007; 65: 261-6.

17. Gupta M, Bansal R, Tiwari G, Sharma S. Aggressive pilomatrixoma: a diagnostic dilemma on fine-needle aspiration cytology with review of literature. Diagn Cytopathol 2014; 42: 906-11.

18. Ieni A, Todaro P, Bonanno AM, Catalano F, Catalano A, Tuccari G. Limits of fine-needle aspiration cytology in diagnosing pilomatrixoma: a series of 25 cases with clinico-pathologic correlations. Indian J Dermatol 2012; 57: 152-5.

19. Lemos MM, Kindblom LG, Meis-Kindblom JM, Ryd W, Willén H. Fine-needle aspiration features of pilomatrixoma. Cancer 2001; 93 : 252-6.

20. Nori J, Abdulcadir D, Giannotti E, Calabrese M. Pilomatrixoma of the breast, a rare lesion simulating breast cancer: a case report. J Radiol Case Rep 2013; 7: 43-50.

21. Bansal C, Handa U, Mohan H. Fine needle aspiration cytology of pilomatrixoma. J Cytol 2011; 28: 1-6.

22. Kumaran N, Azmy A, Carachi R, Raine PA, Macfarlane JH, Howatson AG. Pilomatrixoma--accuracy of clinical diagnosis. J Pediatr Surg 2006; 41: 1755-8. 